\title{
Pendampingan Perencanaan Partisipatif Program Tabungan dan Patungan Kurban Guna Meningkatkan Minat Berkurban di Masa Pandemi
}

\author{
Muhamad Subhi Apriantoro ${ }^{1 *}$, Rafiq Ahmad Zaky ${ }^{2}$, Vivin Dwi Febrianti ${ }^{3}$ \\ 1,2,3 Program Studi Hukum Ekonomi Syari’ah (Mu`amalah), Universitas Muhammadiyah \\ Surakarta, Jalan A. Yani, Mendungan, Pabelan, Kabupaten Sukoharjo, Provinsi Jawa Tengah, \\ Indonesia.
}

Corresponding Email: msa617@ums.ac.id1.

\begin{abstract}
Article History:
Received: Nov 27th 2021

Revised: Dec 1th 2021

Accepted: Dec 8th 2021

Published: Jan 1th 2022

Keywords: Sacrificial

Savings; Participatory

Planning; Muslim

Community; Pandemic.
\end{abstract}

\begin{abstract}
This service activity is carried out to bridge the importance of saving and sacrificial facilities for Muslim congregations from the AsShaykh Jabir Al-Faifi Mosque, Ngasem Village, Colomadu District, Karanganyar Regency, Central Java. Assistance is carried out by previously holding deliberations with the Mosque Prosperity Council to prepare a design for a savings and joint sacrifice scheme which will then be disseminated to local Muslims through the Rukun Neighbor forum and studies at the mosque. The method used to explore and understand the couple's problems is an observation of related informants and documentation. Data analysis used triangulation of data sources. The results of this activity indicate that there is an increase in the enthusiasm of residents in carrying out Qurban worship after the existence of savings products and qurban joint ventures, as can be seen from the increase in the registration of Qurban participants by $60 \%$.
\end{abstract}




\section{Pendahuluan}

Diketahui bahwa 40\% dari 5,6 juta keluarga Muslim di Indonesia melakukan ibadah kurban, dengan asumsi setiap keluarga mengorbankan satu hewan. Permintaan hewan kurban terbesar adalah kambing dan domba yang jumlahnya lebih dari 1,9 juta ekor, sedangkan sapi dan kerbau sekitar 452 ribu ekor. Margin perdagangan ternak 20\% dan harga produsen rata-rata Rp1,9 juta per ekor untuk kambing/domba dan Rp15 juta per ekor untuk sapi/kerbau, nilai ekonomi kurban 2020 sekitar Rp20,5 triliun. Dengan asumsi bobot domba antara 20 hingga $80 \mathrm{~kg}$ dengan bobot karkas 42,5 persen serta sapi dan kerbau dengan bobot antara 250 hingga $750 \mathrm{~kg}$ dengan bobot karkas 50\%, maka kurban 2020 sebanyak 2,3 juta hewan memiliki potensi ekonomi sebesar 117 ribu ton daging. Sebagai perbandingan, produksi daging sapi dan kerbau nasional pada 2019 mencapai 514 ribu ton, sedangkan produksi daging kambing dan domba 163 ribu ton. Fakta ini menunjukkan bahwa ibadah kurban memiliki potensi ekonomi yang besar. Angka ini cenderung meningkat setiap tahun didorong semakin matangnya pemahaman masyarakat tentang esensi ibadah kurban sebagai sarana mendekat kepada Tuhan [1] dan sarat akan nilai-nilai pendidikan [2].

Dalam praktiknya, masyarakat cenderung bertindak insidental dalam mengeluarkan biaya kurban, di mana pembayaran biaya kurban dilakukan mendekati atau pada hari raya Idul adha. Hal ini bagi sebagian kalangan menengah cukup mudah dilakukan mengingat pendapatan harian telah tercukupi. Namun bagi kalangan ekonomi bawah atau sebagian menengah yang terdampak pandemi Covid-19 akan lebih sulit, maka semangat berkurban rentan terhambat disebabkan kurang matangnya perencanaan keuangan.

Lembaga Keuangan Syariah secara umum telah mengeluarkan produk-produkyang membantu masyarakat muslim untuk melaksanakan kurban dengan skema perencanaan. Semisal Rumah Zakat yang berkolaborasi dengan mitra perbankan yakni Bank Mega Syariah dan Bank Jatim Syariah menggagas program Tabungan Qurban (Taqur) [3]. PT Bank Muamalat Indonesia Tbk (Bank Muamalat) membuat produk Tabungan iB Hijrah Rencana Kurban guna memudahkan masyarakat dalam melaksanakan ibadah kurban setiap tahunnya [4].

Badan usaha mandiri terpadu syariah seperti BMT (Baitul Maal wa Tamwil) juga menawarkan produk tabungan perencanaan kurban. Sebagai contoh BMT AUM (Amanah Ummah) menawarkan produk Simpanan Qurban yaitu jenis tabungan yang menggunakan prinsip bagi hasil dan secara khusus diperuntukkan ibadah kurban. Simpanan Qurban menggunakan Akad mudharabah mutlaqah [5]. BMT (Baitul Maal wat Tamwil) Sidogiri meluncurkan produk perlindungan tabungan rencana untuk ibadah kurban bersama dengan Asuransi Syariah Mikro Sarana Sejahtera (Asyki) dan STEI Tazkia [6].

Dari berbagai layanan yang ada, masih minim program yang dilakukan secara mandiri dari masjid untuk mewadahi masyarakat dalam melakukan perencanaan ibadah 


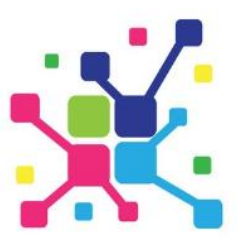

kurban sebagai tanggung jawab DKM untuk memberikan pelayanan yang baik bagi jamaah. Hal ini tentu tidak sebanding dengan antusiasme yang besar dari masyarakat muslim untuk berkurban tiap tahunnya.

Pengurus masjid yang telah diserahi tanggung jawab mengelola masjid sesuai fungsinya memberikan kontribusi yang signifikan terhadap profitabilitas masjid. Pengurus memberikan dorongan bagi mereka yang ingin memperluas masjid dan meragamkan kegiatan yang tersedia untuk masyarakat sekitar. Pengurus masjid harus tegas dan ikhlas dalam menjalankan tugasnya, dan tidak boleh sembarangan atau setengah hati [7]. Masjid yang dikelola secara baik akan membuahkan hasil yang baik pula termasuk diantaranya adalah kesejahteraan jamaahnya secara khusus dan masyarakat luas secara umum.

Fenomena yang kerap terjadi di tengah warga, ditemukan banyak masjid tetapi hanya berperan untuk tempat sholat. Masjid belum difungsikan secara maksimal aktivitas kenaikan mutu jamaah serta pengurus [8]. Sebagian masjid terus melaksanakan pembangunan fisik tanpa mengindahkan penyusunan sistem manajerial yang tujuan akhirnya merupakan kenaikan kualitas jamaah terutama penjagaan terhadap harta dan jiwa terlebih pada masa pandemi [9].

Masyarakat Desa Ngasem, Kecamatan Colomadu, Kabupaten Karanganyar mayoritas beragama Islam dengan angka 70,573 orang, Kristen Katholik 3.704 orang, Kristen Protestan 5.533 orang dan Budha 52 orang. Di Kecamatan Colomadu pada tahun 2018 terdapat tempat ibadah, yaitu masjid 101 unit, mushola 40 unit, gereja 17 unit [10]. Ngasem merupakan kelurahan (desa) sangat barat dari wilayah kabupaten Karanganyar yang berada di kecamatan Colomadu berbatasan dengan tiga kabupaten, yaitu kabupaten Boyolali pada batas barat dan utara, kabupaten Sukoharjo pada batas selatan dan Kota Surakarta pada batas timur. Desa ini sangat terjangkau dari akses perkotaan atau publik lainnya, yang menjamin pasokan informasi dan sumber daya yang memadai. Mata pencaharian masyarakat desa Ngasem relatif beragam. Permukiman ini terletak pada segitiga emas dan berfungsi sebagai penghalang terhadap ekspansi Kota Solo ke arah barat. Mata pencaharian masyarakat sangat bervariasi diantaranya pemerintahan sipil, TNI AU, petani, pedagang, pegawai swasta, dan buruh.

Dari variasi pendapatan ini, sebagian masyarakat tidak dapat menghindar dari dampak pandemi Covid-19. Terutama mereka yang mengandalkan pekerjaan sehari-hari untuk menghidupi keluarganya [11]. Ditambah lagi fakta bahwa kecamatan Colomadu adalah kecamatan dengan angka positif terbanyak dengan jumlah positif 302 pasien setelah kecamatan Karanganyar dengan jumlah 264 pasien dan kecamatan Jaten sejumlah 226 [12]. Hal ini tentu sangat berpengaruh pada kecenderungan berkurban bagi masyarakat terdampak. 

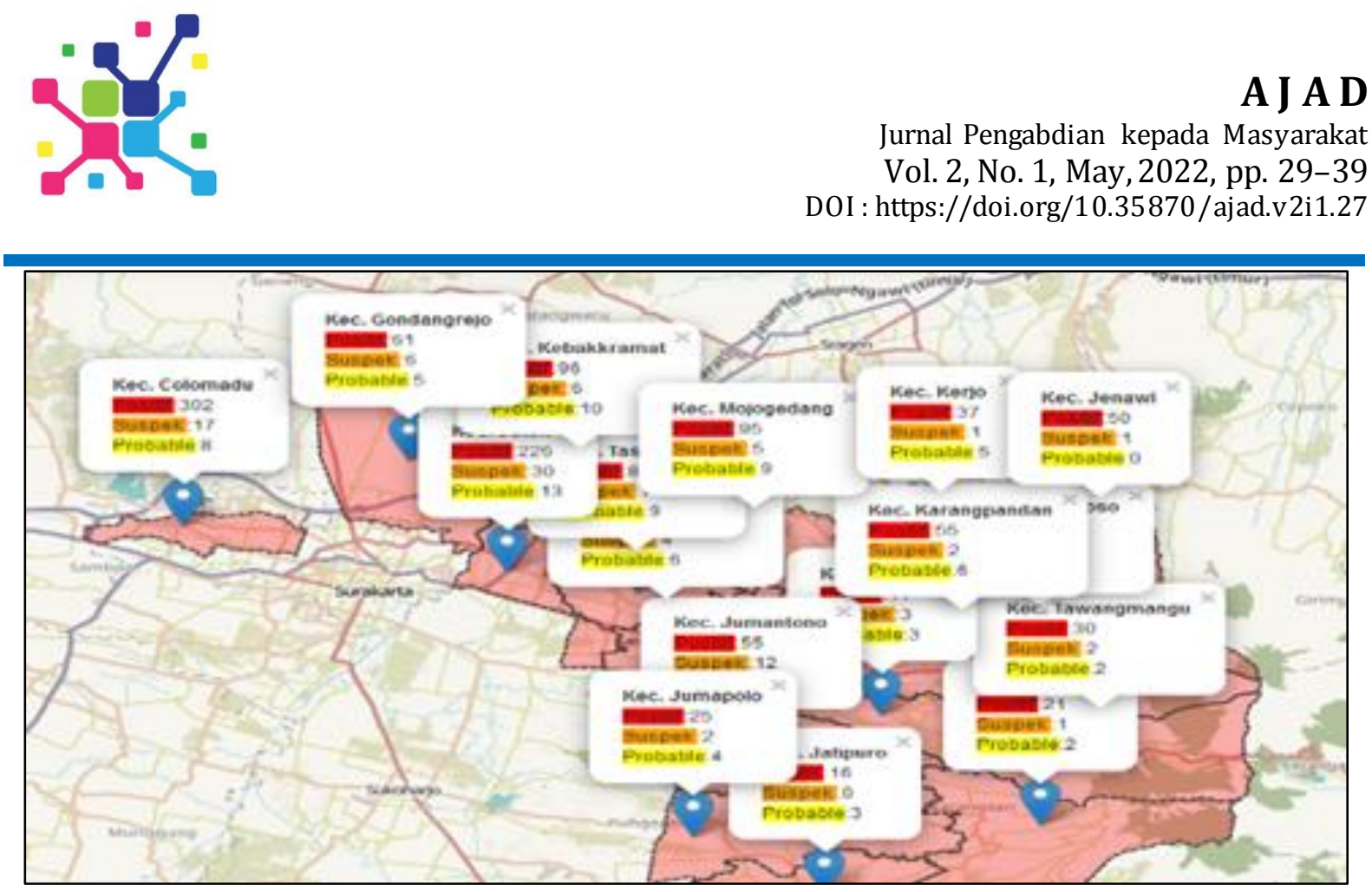

Gambar 1. Peta Data Covid Kab. Karanganyar (Jumat, 23 Juli 2021)

Berdasarkan observasi yang dilakukan, terdapat beberapa permasalahan yang dihadapi oleh masyakat yaitu kurangnya aplikasi materi ceramah, keterbatasan kemampuan penceramah dan belum optimalnya sisi manajerial masjid, adanya sebagian warga yang terdampak secara ekonomi oleh pandemi namun tetap ingin merealisasikan niatnya berkurban menjadi latar belakang diperlukannya pengabdian kepada kelompok masyarakat ini.

\section{Metode}

a. Metode Pelaksanaan Kegiatan

Alur kegiatan pengabdian masyarakat penguatan pengabdian masyarakat pendampingan perencanaan partisipatif program tabungan dan patungan kurban masjid As-Syaikh Jabir Al-Faifi desa Ngasem Colomadu Karanganyar seperti pada gambar 2.

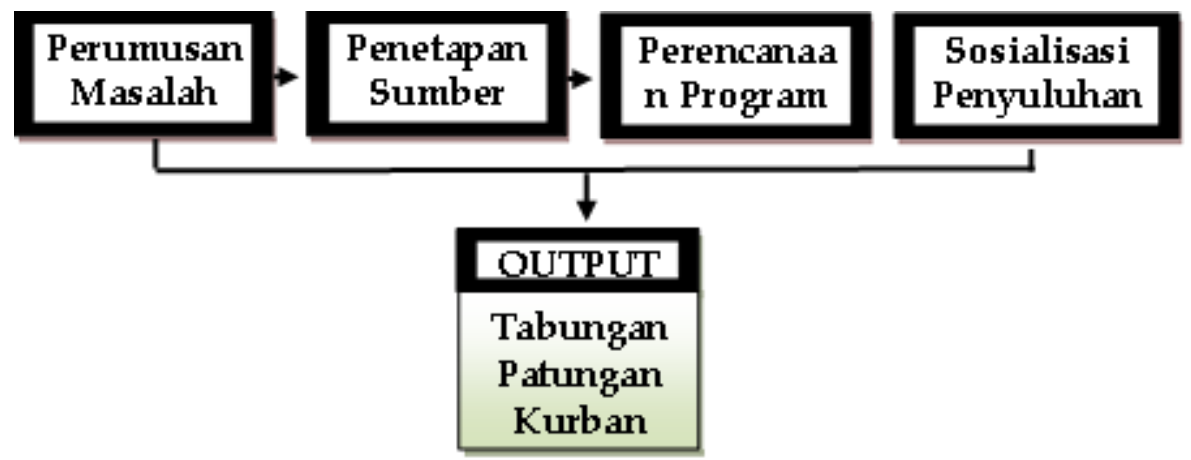

Gambar 2. Alur pelaksanaan kegiatan

Pendekatan yang digunakan adalah PRA (Participatory Rural Appraisal) kualitatif yaitu pengumpulan data/informasi dari berbagai literatur terpercaya tentang status masyarakat, termasuk aspek ekonomi, sosial budaya, agama, dan pendidikan, baik 
dengan telaah dokumen maupun dengan wawancara kepada pihak terkait bekerja sama dengan Dewan Kemakmuran Masjid dan perwakilan warga [13]. Tujuan perencanaan partisipatif dalam program Tabungan Kurban bukan untuk mengambil alih pengambilan keputusan tetapi untuk menunjukkan konsekuensi dari setiap keputusan masyarakat; dengan kata lain, penyuluh bertindak sebagai fasilitator dalam proses pengambilan keputusan, memastikan bahwa keputusan yang dibuat rasional.

Setiap tahap, mulai dari identifikasi masalah dan perumusan kebutuhan hingga perencanaan dan pemrograman, implementasi, operasi, dan pemeliharaan, merupakan upaya kolaboratif antara para pihak yang terlibat (DKM dan masyarakat), dengan demikian seluruh proses perencanaan menjadi pengalaman belajar bagi semua pihak. Penyuluh berperan sebagai katalis dalam hal ini, sedangkan masyarakat berperan sebagai pihak yang diberdayakan dan dibantu oleh DKM untuk bertindak sebagai aktor utama dalam menyelesaikan masalahnya sendiri melalui usahanya sendiri. Hanya pada tahap penelitian, perumusan masalah, identifikasi daya dukung, dan perumusan tujuanlah proses partisipatif yang melibatkan masyarakat berlangsung, bukan pada tahap pemilihan prosedur dan rancangan anggaran tertentu [14].

\section{b. Waktu Efektif Pelaksanaan Kegiatan}

Pelaksanaan kegiatan pendampingan perencanaan partisipatif program tabungan dan patungan kurban guna meningkatkan minat berkurban di masa pandemi dilaksanakan pada Tanggal 13-19 Juli 2021.

\section{c. Tempat Kegiatan}

Pelaksanaan Kegiatan di Desa Ngasem khususnya Peserta kegiatan pengabdian masyarakat ini adalah pengurus DKM masjid As-Syaikh Jabir Al-Faifi berjumlah 34 orang dan perwakilan warga dari beberapa RT dalam RW 11 berjumlah 10 orang.

\section{Hasil}

Hasil analisis kebutuhan kepada jamaah masjid dari angket yang diberikan diketahui bahwa 95\% jamaah pernah mendapatkan materi tentang fikih kurban dari kajian yang diadakan oleh DKM. Sebanyak 68\% mengungkapkan bahwa pemateri pengajian memberikan motivasi keutamaan melaksanakan ibadah kurban.

Sebanyak 74\% jamaah menyetujui bahwa perencanaan keuangan dapat membantu terealisasinya ibadah kurban, namun hanya 43\% dari jamaah yang pernah melakukan perencanaan keuangan untuk ibadah kurban. Sebanyak 54\% membutuhkan adanya tabungan kurban untuk mendisiplinkan perencanaan ibadah kurban. Jamaah dengan jumlah persentase $63 \%$ menyatakan setuju dengan adanya produk tabungan kurban yang difasilitasi oleh masjid.

Dari hasil musyawarah dengan DKM dan perwakilan jamaah dihasilkan produk tabungan kurban dengan sifat titipan (wadiah), dimana peserta hanya mengamanahi 


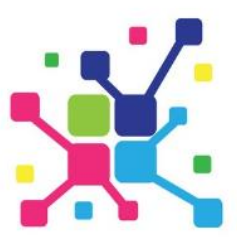

A J A D

Jurnal Pengabdian kepada Masyarakat

Vol. 2, No. 1, May, 2022, pp. 29-39

DOI : https://doi.org/10.35870/ajad.v2i1.27

titipan dana kepada petugas DKM tanpa memperoleh bunga ataupun potongan biaya administrasi apapun [15]. Terdapat dua jenis tabungan yang diberlakukan yaitu tabungan mengikat dan tabungan tidak mengikat.

Tabungan mengikat diniatkan khusus untuk membeli hewan kurban pada tahun mendatang. Dana pada tabungan mengikat tidak dapat diambil hingga waktu yang ditentukan. Besaran setoran bersifat wajib dengan perhitungan setoran disesuaikan dengan jenis hewan kurban. Pengembalian dana tabungan di akhir waktu berupa hewan kurban yang telah ditentukan jenisnya pada awal menabung. Kelebihan dana tabungan dikembalikan kepada penabung. Jika terjadi kekurangan penabung menambahkan dana kekurangan. Tabungan jenis ini berlaku selama satu tahun dan diperbarui pada satu tahun berikutnya.

Tabungan tidak mengikat bertujuan sebagai pengenalan dan pembelajaran kepada peserta. Setoran bulanan bersifat wajib dengan jumlah yang fleksibel. Peserta dapat mengambil utuh dana tabungannya untuk kemudian membeli hewan qurban secara mandiri atau dapat mewakilkan pada takmir untuk membelikan hewan qurban dengan menambahkan jumlah dana kekurangan (jika terjadi kekurangan) atau dapat melakukan perpanjangan masa tabungan hingga mencapai dana sesuai skema.

Adapun skema harga dan angsuran tabugan mengikat yang disepakati dijelaskan pada tabel 1 dan 2 .

Tabel 1. Skema Tabungan Mengikat Kambing/Domba

\begin{tabular}{|c|c|c|c|c|c|}
\hline $\begin{array}{l}\text { HEWAN } \\
\text { KURBAN }\end{array}$ & $\begin{array}{c}\text { WAKTU } \\
\text { ANGSURAN }\end{array}$ & PERIODE & $\begin{array}{l}\text { ANGSURAN } \\
\text { PER BULAN }\end{array}$ & KELEBIHAN & $\begin{array}{c}\text { JUMLAH } \\
\text { DANA } \\
\text { KURBAN }\end{array}$ \\
\hline $\begin{array}{l}1 \\
\text { kambing/ } \\
\text { domba }\end{array}$ & $\begin{array}{l}10 \text { Bulan } \\
9 \text { Bulan } \\
8 \text { Bulan } \\
7 \text { Bulan } \\
6 \text { Bulan } \\
5 \text { Bulan } \\
4 \text { Bulan } \\
3 \text { Bulan } \\
2 \text { Bulan }\end{array}$ & $\begin{array}{l}\text { Agustus 2021-31 Mei } 2022 \\
\text { September 2021-31 Mei } 2022 \\
\text { Oktober 2021-31 Mei } 2022 \\
\text { November 2021-31 Mei } 2022 \\
\text { Desember 2021-31 Mei2022 } \\
\text { Januari 2021-31 Mei } 2022 \\
\text { Februari 2021-31 Mei } 2022 \\
\text { Maret 2021-31 Mei } 2022 \\
\text { April 2021-31 Mei } 2022\end{array}$ & $\begin{array}{l}\text { Rp 250.000,- } \\
\text { Rp 280.000,- } \\
\text { Rp 315.000,- } \\
\text { Rp360.000,- } \\
\text { Rp 420.000,- } \\
\text { Rp 500.000,- } \\
\text { Rp 625.000,- } \\
\text { Rp 670.000,- } \\
\text { Rp } 1.250 .000,-\end{array}$ & $\begin{array}{l}\text { Rp 0,- } \\
\operatorname{Rp} 20.000,- \\
\operatorname{Rp} 20.000,- \\
\operatorname{Rp} 20.000,- \\
\operatorname{Rp} 20.000,- \\
\operatorname{Rp} 0,- \\
\operatorname{Rp} 0,- \\
\operatorname{Rp} 10.000,- \\
\operatorname{Rp} 0,-\end{array}$ & $\begin{array}{l}\text { Rp } 2.500 .000,- \\
\text { Rp } 2.500 .000,- \\
\text { Rp } 2.500 .000,- \\
\text { Rp } 2.500 .000,- \\
\text { Rp } 2.500 .000,- \\
\text { Rp } 2.500 .000,- \\
\text { Rp } 2.500 .000,- \\
\text { Rp } 2.500 .000,- \\
\text { Rp } 2.500 .000,-\end{array}$ \\
\hline
\end{tabular}

Tabel 2. Skema Tabungan Mengikat Patungan Sapi

\begin{tabular}{|c|c|c|c|c|c|}
\hline $\begin{array}{l}\text { HEWAN } \\
\text { KURBAN }\end{array}$ & $\begin{array}{c}\text { WAKTU } \\
\text { ANGSURAN }\end{array}$ & PERIODE & $\begin{array}{l}\text { ANGSURAN } \\
\text { PER BULAN }\end{array}$ & KELEBIHAN & $\begin{array}{c}\text { JUMLAH } \\
\text { DANA } \\
\text { KURBAN }\end{array}$ \\
\hline 1/7 sapi & $\begin{array}{l}10 \text { Bulan } \\
9 \text { Bulan } \\
8 \text { Bulan } \\
7 \text { Bulan } \\
6 \text { Bulan } \\
5 \text { Bulan } \\
4 \text { Bulan } \\
3 \text { Bulan } \\
2 \text { Bulan }\end{array}$ & $\begin{array}{l}\text { Agustus 2021-31 Mei } 2022 \\
\text { September 2021-31 Mei } 2022 \\
\text { Oktober 2021-31 Mei } 2022 \\
\text { November 2021-31 Mei } 2022 \\
\text { Desember 20121-31 Mei } 2022 \\
\text { Januari 2021-31 Mei } 2022 \\
\text { Februari 2021-31 Mei } 2022 \\
\text { Maret 2021-31 Mei } 2022 \\
\text { April 2021-31 Mei } 2022\end{array}$ & $\begin{array}{l}\text { Rp 300.000,- } \\
\text { Rp 335.000,- } \\
\text { Rp 375.000,- } \\
\text { Rp 430.000,- } \\
\text { Rp 500.000,- } \\
\text { Rp 600.000,- } \\
\text { Rp 750.000,- } \\
\text { Rp 1.000.000,-- } \\
\text { Rp 1.500.000,-- }\end{array}$ & $\begin{array}{l}\text { Rp 0,- } \\
\operatorname{Rp} 15.000,- \\
\operatorname{Rp} 0,- \\
\operatorname{Rp} 10.000,- \\
\operatorname{Rp~0,-} \\
\operatorname{Rp~0,-} \\
\operatorname{Rp~0,-} \\
\operatorname{Rp~0,-} \\
\operatorname{Rp} 0,-\end{array}$ & $\begin{array}{l}\text { Rp 3.000.000,- } \\
\text { Rp 3.000.000,- } \\
\text { Rp 3.000.000,- } \\
\text { Rp 3.000.000,- } \\
\text { Rp 3.000.000,- } \\
\text { Rp 3.000.000,- } \\
\text { Rp 3.000.000,- } \\
\text { Rp 3.000.000,- } \\
\text { Rp 3.000.000,- }\end{array}$ \\
\hline
\end{tabular}




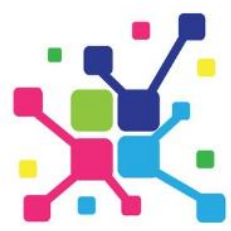

A J A D

Jurnal Pengabdian kepada Masyarakat

Vol. 2, No. 1, May, 2022, pp. 29-39

DOI : https://doi.org/10.35870/ajad.v2i1.27

Dalam keadaan tertentu, DKM dapat memberikan subsidi bagi penabung yang dananya belum mencapai angka yang diinginkan. Semisal dalam kasus pengkurban sapi yang belum mencapai kelompok patungan penuh (tujuh pengkurban). Subsidi ini diberikan kepada peserta yang dinyatakan layak oleh DKM setelah dilakukan musyawarah dengan berbagai pihak. Menjelang Idul Adha atau pelaksanaan kurban, panitia memberikan informasi kepada peserta paling lambat tiga minggu sebelum hari $\mathrm{H}$ dalam bentuk surat yang berisi sekurang-kurangnya terdiri dari jumlah uang tabungan, harga hewan kurban (jika perlu mengikuti perubahan), kekurangan atau kelebihan atas biaya pelaksanaan kurban dan konfirmasi pelaksanaan kurban.

Harga yang tertera sudah termasuk semua biaya operasional, seperti sosialisasi, pengadaan hewan, penyembelihan, distribusi, pemantauan, dokumentasi, dan pelaporan, serta biaya-biaya lain yang timbul. DKM berhak menentukan wilayah distribusi dengan memprioritaskan wilayah yang paling membutuhkan baik di lingkungan masjid atau di luar.

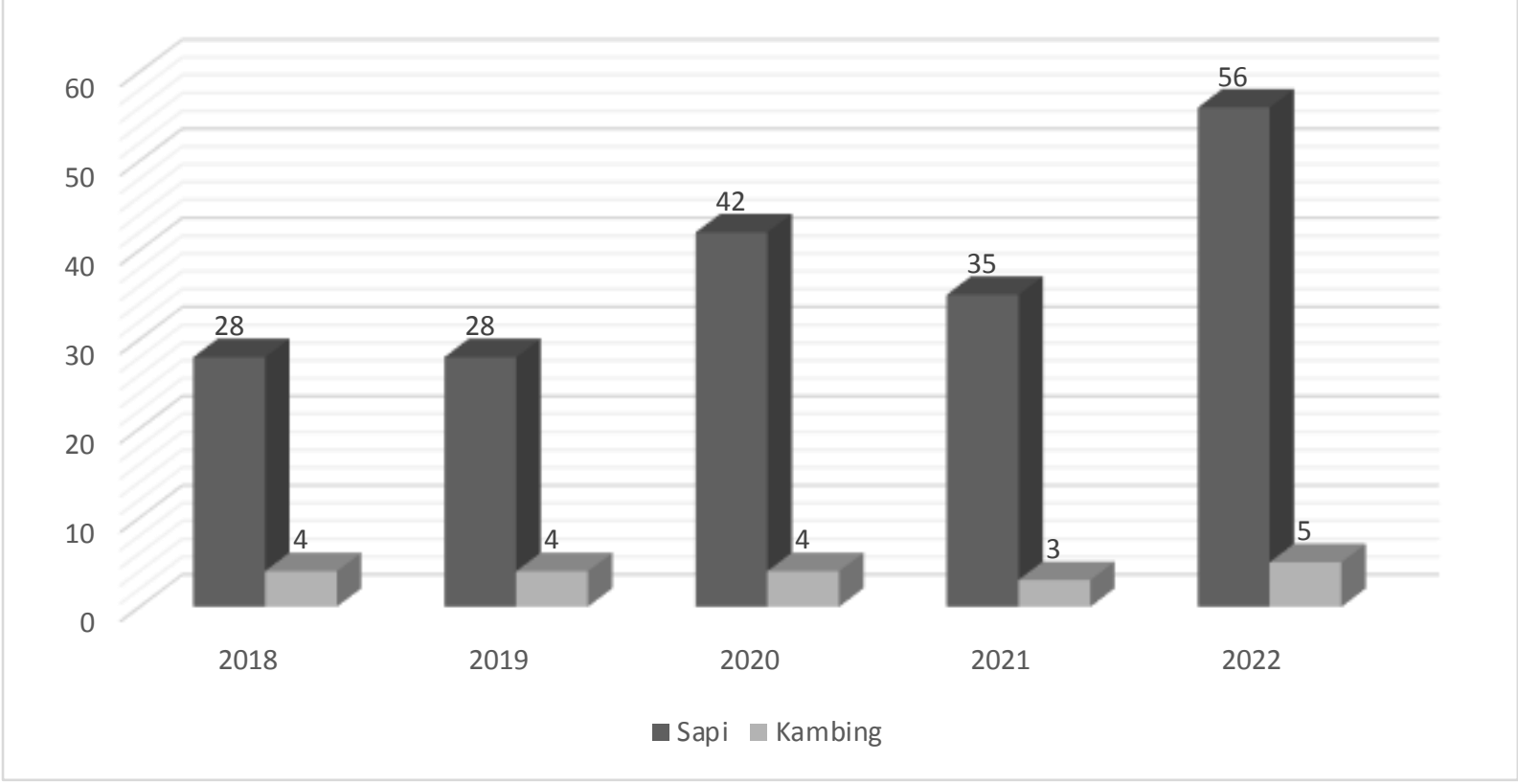

Grafik 1. Data Peserta Kurban

Pada grafik 1 data peserta kurban, diketahui bahwa jumlah peserta dari tahun 2018 hingga 2021 mengalami fluktuasi. Pada tahun 2018 dan 2019 jumlah peserta mengalami kesamaan dari sapi dan kambing. Pada tahun 2020 mengalami kenaikan 14 orang peserta sapi namun sama dalam jumlah pengkurban kambing. Pada tahun 2021 jumlah peserta sapi mengalami penurunan 7 orang dan pengkurban kambing 1 orang. Diketahui dari hasil wawancara kepada 7 pengkurban yang mundur disebabkan dampak ekonomi dari pandemi. Setelah diadakan program tabungan patungan kurban pada tahun 2022 mendatang jumlah pendaftar untuk peserta kurban sapi mengalami kenaikan $60 \%$ sejumlah 21 peserta atau tiga kelompok patungan, dan pendaftar untuk peserta kambing mengalami kenaikan sejumlah 2 peserta. 

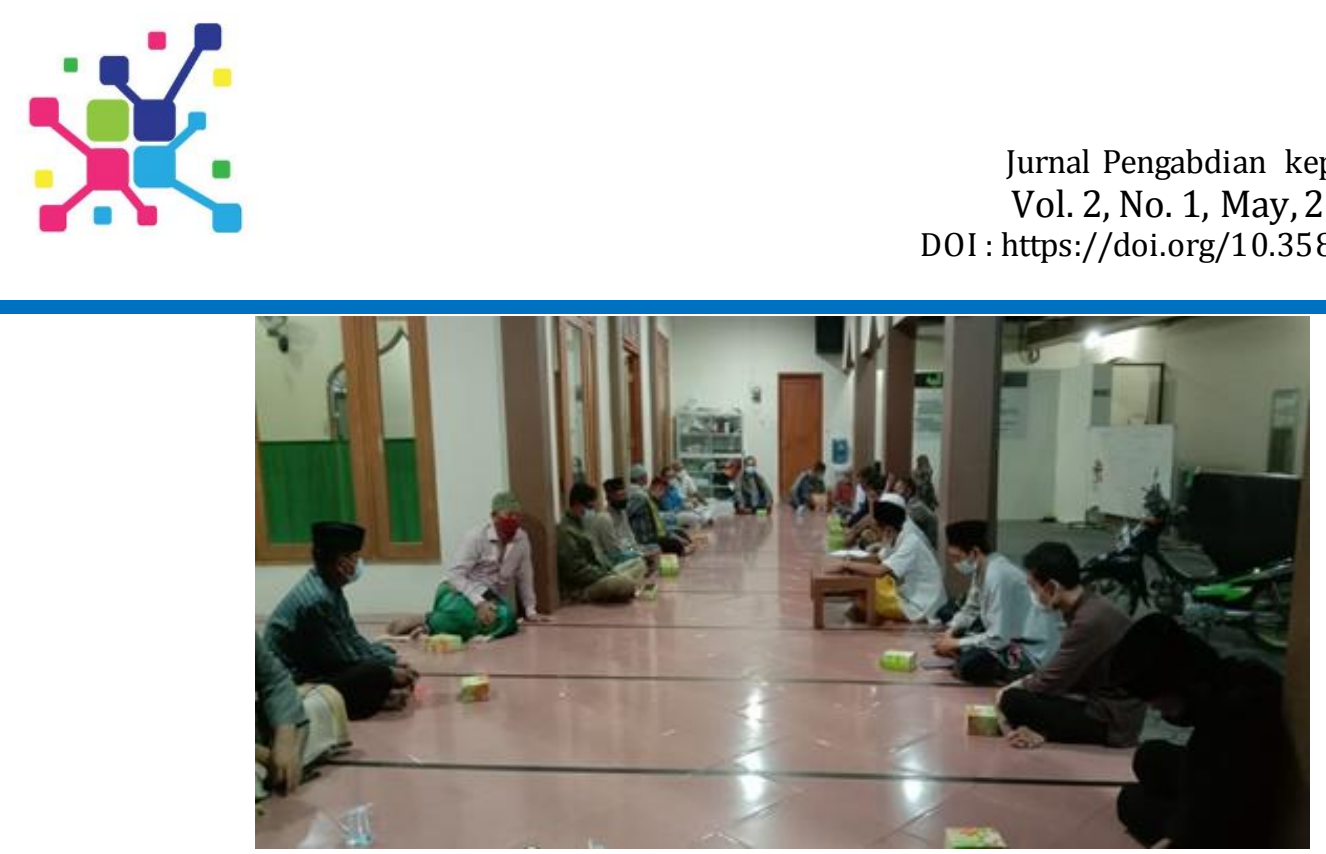

Gambar 3. Partisipasi Masyarakat Dalam Perencanaan Program

\section{Diskusi}

Pertemuan tatap muka akan dilakukan dengan peserta memakai masker, mencuci tangan, dan mengukur suhu tubuh sebelum pertemuan dimulai. Hal ini menandakan bahwa setiap orang berada pada suhu tubuh yang normal sebelum pertemuan, sehingga musyawarah akan berjalan dengan baik [16]. Informasi dan pemikiran awal disusun secara ringkas dalam bahasa yang sederhana. Manajemen DKM memiliki pilihan untuk menyuarakan reaksi dan tanggapannya setelah penyampaian materi dilakukan melalui diskusi dan interaksi interaktif. Sebagai hasil dari wacana partisipatif, jamaah dapat mengungkapkan keprihatinan mereka saat ini tentang tabungan kurban, yang akan bersama dimusyawarahkan untuk menemukan jawabannya.

Peserta kegiatan pengabdian masyarakat ini adalah pengurus DKM masjid AsSyaikh Jabir Al-Faifi berjumlah 34 orang dan perwakilan warga dari beberapa RT dalam RW 11 berjumlah 10 orang. Instrumen yang digunakan adalah lembar kuisioner yang diberikan kepada jamaah muslim masjid As-Syaikh Jabir Al-Faifi sebanyak 210 responden untuk mengetahui dan menganalisa kebutuhan warga muslim akan tabungan kurban. Tahap-tahap yang akan ditempuh dalam pengabdian ini terdiri dari lima tahap, yaitu inisiatif perencanaan, pengkondisian sosial, survei, perencanaan partisipatif, evaluasi. Kelima tahapan tersebut dijelaskan dalam tabel 3.

Tabel 3. Tahapan kegiatan

\begin{tabular}{llll}
\hline \multicolumn{1}{c}{ Tahapan } & \multicolumn{1}{c}{ Uraian Kegiatan } & Metode \\
\hline $\begin{array}{l}\text { Inisiatif } \\
\text { perencanaan }\end{array}$ & Inisiatif perencanaan berasal dari Dewan & Dialog \\
\hline Pengkondisian & Sebelum memulai proses perencanaan & $\bullet$ Perkenalan \\
sosial & partisipatif, tahap ini melibatkan & $\bullet$ Pendekatan \\
& pendidikan, pelatihan, dan pembentukan & $\bullet$ Dialog \\
& sikap di antara anggota masyarakat dan & \\
& pembuat kebijakan. & \\
\hline
\end{tabular}




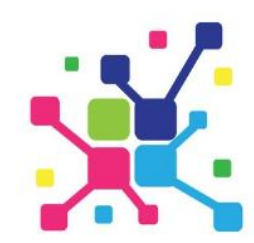

\begin{tabular}{|c|c|c|}
\hline Survei & $\begin{array}{l}\text { Survei kondisi lingkungan dilakukan untuk } \\
\text { lebih memahami masalah yang ada dan } \\
\text { solusi potensial. }\end{array}$ & $\begin{array}{l}\text { - Pelatihan } \\
\text { - Penilaian } \\
\text { cepat } \\
\text { - Community } \\
\text { Diagnostic }\end{array}$ \\
\hline $\begin{array}{l}\text { Perencanaan } \\
\text { partisipatif }\end{array}$ & $\begin{array}{l}\text { Pada langkah ini, tim menyepakati } \\
\text { tantangan yang harus dipecahkan, jumlah } \\
\text { perbaikan, dan alokasi sumber daya. } \\
\text { Dilanjutkan dengan pemaparan dan } \\
\text { pembahasan draf rancangan tabungan } \\
\text { patungan kurban. }\end{array}$ & $\begin{array}{ll}- & \text { FocusGroup } \\
& \text { Discussion } \\
\text { - } & \text { SWOT } \\
\text { - } & \text { Participatory } \\
& \text { Planning }\end{array}$ \\
\hline Evaluasi & $\begin{array}{l}\text { Melakukan review produk dan penekanan } \\
\text { tidak hanya pada temuan evaluasi tapi juga } \\
\text { proses partisipasi sehingga hasil evaluasi } \\
\text { dapat menjadi masukan untuk formulasi } \\
\text { dan revisi perencanaan yang lebih } \\
\text { mencerminkan opini masyarakat. }\end{array}$ & $\begin{array}{ll}\text { - } & \text { Presentasi } \\
\text { - } & \text { laporan } \\
& \text { evaluasi }\end{array}$ \\
\hline
\end{tabular}

Hasil wawancara dengan beberapa jamaah masjid menyatakan bahwa pengkajian materi kurban sudah cukup baik namun sebagian besar terfokus pada kajian teoritik yang mencakup sejarah kurban, dalil pensyariatan, syarat keabsahan dan pandangan antara ulama mazhab. Belum pernah ada kajian yang menyentuh aspek perencanaan keuangan hingga produk yang memudahkan jamaah untuk merealisasikan niat berkurban. Jamaah bertambah antusias ketika kajian-kajian keislaman diiringi dengan kegiatan praktis karena selain memecah kebosanan juga dapat meningkatkan pemahaman serta penghayatan terhadap materi tersebut.

Hasil wawancara dengan ketua dan penguruh harian DKM terungkap bahwa DKM telah menggalakkan berbagai cara untuk memotivasi jamaah melaksanakan ibadah kurban dengan berbagai kegiatan pengajian. Tidak jarang DKM mengundang pembicara dari luar wilayah yang dipandang memiliki pengaruh pada masyarakat. DKM juga telah memberikan sosialisasi melalui pamflet dan edaran yang disampaikan melalui forum rukun tetangga juga PKK. Telah ada inisiatif dari beberapa pengurus DKM untuk mengadakan program tabungan kurban, namun secara umum DKM belum mampu mengoptimalkan sumber daya manusia untuk menyusun konsep yang matang dan dapat disepakati oleh jamaah. Kendala lain yang dihadapi DKM adalah kesibukan harian dari para pengurus yang sebagiannya masih meletakkan kepengurusan DKM sebagai status sampingan bukan sebagai amanah yang perlu ditunaikan secara optimal. Hal ini tentu tidak sejalan dengan salah satu fungsi DKM yaitu sebagai wadah edukasi yang menuntut peranan aktif para pengurusnya dalam memberikan totalitas keteladanan kepada jamaah [17]. 


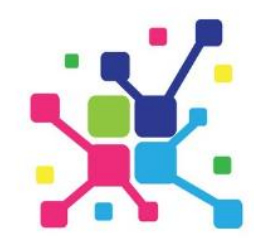

\section{Kesimpulan}

Dengan kegiatan pendampingan perencanaan partisipatif program tabungan dan patungan kurban ini, masyarakat Desa Ngasem khususnya jamaah masjid As -Syaikh Jabir Al-Faifi pada masa pandemi ini merasa terbantu dalam sisi ibadah, sosial dan ekonomi. Selain itu, jamaah semakin menyadari pentingnya sebuah perencanaan ekonomi untuk meningkatkan kesejahteraan hidup. Para pengurus DKM juga telah menyadari akan pentingnya manajemen masjid yang baik sebagai tanggung jawab terhadap amanah kepengurusan. Kepengurusan tidak hanya dipahami sebagai beban, namun juga ladang amal yang diwujudkan dalam pelayanan optimal kepada para jamaah. Yang terpentinng dari semua itu, telah tumbuhnya kesadaran bahwa DKM dan jamaah adalah dua unsur utama terbentuknya komunitas kebaikan di masyarakat secara luas jika keduanya saling berpartisipasi dan berkolaborasi aktif dalam mengusulkan, menyusun dan menjalankan program-program yang produktif.

\section{Ucapan Terima Kasih}

Terlaksananya kegiatan pengabdian masyarakat ini tidak lebas dari dukungan berbagai pihak. Dalam hal ini, tim pengabdi mengucapkan terimakasih kepada Lembaga Penelitian dan Pengabdian kepada Masyarakat Universitas Muhammadiyah Surakarta, Fakultas Agama Islam Universitas Muhammadiyah Surakarta, Pemerintah Desa Ngasem yang telah memberikan perizinan dan arahan konstruktif, Dewan Kemakmuran Masjid As-Syaikh Jabir Al-Faifi serta warga RW 11, terkhusus RT 05 dan Paguyuban NCD atas partisipasi positifnya dalam kegiatan ini.

\section{Daftar Referensi}

[1] Mahfud, C., 2014. Tafsir sosial kontekstual ibadah kurban dalam Islam. Humanika, Kajian Ilmiah Mata Kuliah Umum, 14(1).

[2] Burga, M.A., Marjuni, A. and Rosdiana, R., 2019. Nilai-nilai Tarbiyah Ibadah Kurban dan Relevansinya dengan Pembelajaran Pendidikan Formal. PALAPA, 7(2), pp.202233.

[3] Republika. Gandeng Dua Bank, Rumah Zakat Kembangkan Tabungan Qurban / Republika Online. Retrieved July 3, 2021, from https://www.republika.co.id/berita/qgdpv1380/gandeng-dua-bank-rumahzakat-kembangkan-tabungan-qurban.

[4] Bank Muamalat Buat Tabungan untuk Kurban/Republika Online. Retrieved July 3, 2021, from https://www.republika.co.id/berita/pw4iec423/bank-muamalatbuat-tabungan-untuk-kurban.

[5] Simpanan Qurban/ BMT Amanah Ummah. Retrieved July 9, 2021, from https://bmtaum.co.id/simpanan-qurban/ 
[6] BMT Sidogiri rilis Asuransi Tabungan Kurban. (n.d.). Retrieved July 9, 2021, from https://keuangan.kontan.co.id/news/bmt-sidogiri-rilis-asuransi-tabungankurban

[7] Caniago, F., \& Ganesha, P. P. 2019. Upaya Takmir Masjid Al-Muhajirin Dalam Meningkatkan Semangat Berkurban Di Masyarakat. Journal.Piksi.Ac.Id, 6, 74-90.

[8] Halawati, F. 2021. Efektifitas Manajemen Masjid yang Kondusif terhadap Peningkatan Kemakmuran Masjid. Jurnal Fakultas Ilmu Keislaman Kuningan. https://www.jurnal.unisa.ac.id/index.php/jfik/article/view/74

[9] Sari, N. K. 2020. Penerapan Maqashid Syariah dalam Manajemen Masjid. At-Tadbir: Jurnal Manajemen Pendidikan Islam. http://ejournal.kopertais4.or.id/sasambo/index.php/atTadbir/article/view/3704

[10] BPS kabupaten Karanganyar. Retrieved July 13, 2021, from https://karanganyarkab.bps.go.id/publication/2019/09/26/f8ff21072f8c294a2c a529c8/kecamatan-colomadu-dalam-angka-2019

[11] Budastra, I. K. 2020. Dampak sosial ekonomi covid-19 dan program potensial untuk penanganannya: studi kasus di kabupaten lombok barat. Jurnal Agrimansion. http://agrimansion.unram.ac.id/index.php/Agri/article/view/321

[12] Informasi Covid-19 Kabupaten Karanganyar. Retrieved July 13, 2021, from https://covid19.karanganyarkab.go.id/

[13] Juriyah. 2021. Profil Implementasi Model Shared pada Pembelajaran IPA Terpadu di Indonesia: Kajian Literatur (2012-2021). Jurnal Inovasi Penelitian Dan Pengabdian Masyarakat, 1(1), 32-46.https://doi.org/10.53621/jippmas.v1i1.6

[14] Ashari, M., 2016. Analisis Perencanaan Pembangunan Daerah di Kabupaten Lombok Utara (Studi Kasus Perencanaan Partisipatif Tahun 2009-2013). Jurnal Ekonomi \& Kebijakan Publik, 6(2), pp.163-180.

[15] Indriasari, R., Muliati, M. and Santoso, A.B., 2018. Persepsi Nasabah tentang Tabungan Wadiah.Jurnal Riset dan Aplikasi: Akuntansi dan Manajemen, 3(1), pp.17.

[16] Saputro, A.A., Saputra, Y.D. and Prasetyo, G.B., 2020. Analisis Dampak Covid-19 Terhadap Kesadaran Masyarakat Dalam Penerapan Protokol Kesehatan. Jurnal Porkes, 3(2), pp.81-92.

[17] Arif, R., Wicaksono, A. W., Andriyanto, A., \& Sholeh, D. 2021. Peningkatan Peran Dewan Kemakmuran Masjid sebagai Fungsi Edukasi dalam Pelaksanaan Kurban di Tengah Pandemi Covid-19. Agrokreatif: Jurnal Ilmiah Pengabdian Kepada Masyarakat, 7(1), 67-75. https://doi.org/10.29244/agrokreatif.7.1.67-75. 